The Natives of the Eastern Portion of Borneo and of Java

Author(s): T. R. H. Garrett

Source: The Journal of the Royal Anthropological Institute of Great Britain and Ireland, Vol. 42

(Jan. - Jun., 1912), pp. 53-67

Published by: Royal Anthropological Institute of Great Britain and Ireland

Stable URL: http://www.jstor.org/stable/2843232

Accessed: 02-01-2016 08:41 UTC

Your use of the JSTOR archive indicates your acceptance of the Terms \& Conditions of Use, available at http://www.jstor.org/page/ info/about/policies/terms.jsp

JSTOR is a not-for-profit service that helps scholars, researchers, and students discover, use, and build upon a wide range of content in a trusted digital archive. We use information technology and tools to increase productivity and facilitate new forms of scholarship. For more information about JSTOR, please contact support@jstor.org. 


\title{
THE NATIVES OF THE EASTERN PORTION OF BORNEO AND OF JAVA.
}

\section{(PRELIMINARY NOTE.)}

\author{
By T. R. H. Garrett, M.A., F.R.G.S.
}

\section{INTRODUCTORY.}

THE observations detailed in the following notes were made during the author's residence in Borneo during the years 1909 and 1910 (with the exception of the measurements of the subjects Nos. 1 to 23 (original) which were made at their homes in Java). The majority of the subjects were the author's coolies, who, as regards the Sundanese and Javanese, were to a certain extent picked men, i.e., though they were not picked as to stature or strength, yet had passed a rather perfunctory medical examination as to general health and soundness. The Banjerese were not picked even to this extent, though the author would not have engaged a man who was obviously unfit to work. Subjects Nos. 1 to 23 (original) were casually taken as they came in response for subjects to be measured. Those numbered 89 to 94 (original) were also casually met with in the jungle.

The results of the observations fall into two main divisions: (1) general notes on the outward appearance and mode of life of the individuals classified according to tribes; (2) a portion of the measurements made and indices with a few comments on the outcome of the comparison of these with other data.

The author hopes to publish with the remainder of the measurements more detailed general ethnological observations on the Banjerese and Orang Bulongan.

\section{General Ethnological Observations.}

\section{(a) Banjerese.}

This term is used in Borneo to signify the original inhabitants of the southeast portion of the island who have embraced Mohammedanism (non-Mohammedans are called by such terms as Orang Bukit and that very much misused term Dyak). The Banjerese have to a certain extent intermarried with the natives of Singapore, Java, and the rest of Borneo, especially the south and east coasts, and to a very small extent with settlers from China, British India, etc., though these latter as a rule keep to themselves. They almost all speak Malay, but they also have a language of their own which originally was distinct from Malay, but now consists of Malay words and distinct words in about equal proportions ; and all the different 
districts (Kendangan, Amuntay, etc.) have distinctive words, so that it is possible to tell a man's district from the words he uses.

About fifty per cent. of the males can write, and of these about one-half can write in Malay characters, about one quarter in both Malay and Roman characters, and the other quarter in Roman characters only.

Physically, they are not very strong and do not care for continual manual labour, and hence are not greatly employed as general coolies when other labour is available. But they make skilful artizans (such as carpenters, blacksmiths, etc.), and are especially clever at work in the jungle or on the river : for such work one Banjerese is worth two or three Sundanese or Javanese.

They are very intelligent, being readily taught clerical or observational work (such as in the laboratory or elementary surveying). Their sense of responsibility is as high as, if not higher than, that of any Eastern people I have come in contact with.

Neatness of dress is a marked characteristic, many spending much on clothing ; in fact, many would be rightly described as dandies.

\section{(b) Orang Balik Papan.}

On the immediate coast of East Borneo, and in the larger villages near the mouths of the rivers, the original population has been displaced by the Banjerese, Bugis, Bajau (and further north Sulu), or so mixed with them as to be unrecognizable. But occasionally in more unfrequented places, and especially on the smaller rivers about the limit of tidal influence, may be found a few small communities which represent the original inhabitants of the coast. One such I came across in the Orang Balik Papan, who live half a mile from the mouth of the Sungei Penjangulin which flows into the head of the Balik Papan Bay. They assert that they are the original inhabitants of the district. In appearance they are sparely built, without any superfluous flesh, and they do not trouble much about washing. They circumcize, but not till immediately before marriage. Their language closely resembles that spoken in Pasir, the district to the south of Balik Papan, so much so that one of my men who could speak the Pasir language could understand a little when the Orang Balik Papan were speaking amongst themselves. They do not understand Bugis or Bajau at all, and but very little Malay, with few exceptions.

In 1910 the Kampong community consisted of about half a dozen houses, but formerly it was much larger. They are very closely intermarried, and do not seem to marry outside of their own people. They are very improvident, when they have rice (grown or bought with the proceeds of the sale of rotan and rubber) they hold a succession of feasts until it is finished, when they seem to use as their staple food a tripang found in the mud at low water. When I was there the daughter of the Patinggi (head of the village) had just been married. A great feast had been held and everything eaten up, with the result that the men had to go into the jungle to get rotan and rubber, with which to buy rice, without any food: even the children had had nothing to eat the day I met them. 
They wear the short Bugis trousers in the jungle, but in bis house the Patinggi was wearing only a small chawat (waist cloth). The women wear an ordinary Malay type of home-made Kain Sarong.

They are not Mohammedans, and the Patinggi declared that he did not think religion was worth considering (tidah perduli): they eat pigs but not monkeys. In appearance and habits they are similar to the other people of the immediate neighbourhood.

Sondro is diminutive, almost a dwarf, and certainly a partial idiot; he does but little work, not enough to support a wife (one had divorced him after a year for this reason), now he lives mainly on his brother.

\section{(c) Orang Tarakan.}

The Orang Tarakan are the natives of the small island of Tarakan near the mouth of the Batang Kayan (or Bulongan River). The total number of these probably does not exceed three hundred, and they are much mixed with Bugis, Bulongan, Sulu, and Banjerese. Their language is a distinct one, and the Bulongan people cannot understand it; it is not written. In appearance the Orang Tarakan resemble the Bugis and Bajau.

\section{(d) Orang Bulongan.}

These live near the mouth of the Batang Kayan. They are extremely mixed with the Bugis, Bajau, Banjerese, Sulu, and some little Kayan. They are probably not the original inhabitants of the district, but immigrants who have forced the Kayan, Punan, Menglihat, and similar tribes away from the mouth of the river.

\section{(e) Bugis.}

These are all immigrants into Borneo: many naturally so, but there is a tradition that an epidemic of smallpox almost depopulated the east coast about the middle of the last century, and that the Rajahs, especially the Sultan of Kutei, bought Bugis from the Rajahs in Celebes, especially of Sidendreng, to repopulate their territories. At the present time I have observed that frequently praus come over from Celebes with Bugis who then clear a piece of ground and build a house and remain on the Kutei coast for about a couple of years; then others come over and take their place or build a house near at hand, and the old ones return home. There is also constant communication now by steamer with the coast ports of Celebes.

\section{(f) Batavian Malay.}

The people living near Batavia who call themselves Malay, as distinct from Sundanese and Javanese, are of very mixed origin.

\section{Physical Anthropology.}

The measurements were made with Martin's anthropometer, etc., while age, colour of skin, and eye were recorded in the manner described (see legenda to 
Table 1). The results are embodied in Tables 1 and 2, which show a portion of the observations made, and in regard to these the following comments are appropriate :-

\section{Comparison of Measurements and Indices.}

$$
\text { a. Averages. }
$$

Of the Banjerese I have been unable to find any previous measurements, except one by Hagen, but Deniker ${ }^{1}$ and Hagen ${ }^{2}$ give some figures for the Javanese and Sundanese. Hagen divides his subjects into three groups: (1) under 20 years of age; (2) 20 to 34 , and (3) 34 to 60 . The figures quoted below have been obtained by combining groups (2) and (3).

\begin{tabular}{|c|c|c|c|c|c|c|}
\hline & & & \multirow{2}{*}{ Stature. } & \multicolumn{2}{|c|}{ Head. } & \multirow{2}{*}{ Cephalic Index. } \\
\hline & & & & Length. & Breadth. & \\
\hline $\begin{array}{lll}\text { Banjerese } \ldots & \ldots\end{array}$ & $\ldots$ & $\ldots$ & $1569 \cdot 6$ & $181 \cdot 2$ & $147 \cdot 4$ & $81 \cdot 48$ \\
\hline Boyanese (Hagen) & $\ldots$ & ... & $1616 \cdot 1$ & $178 \cdot 7$ & $149 \cdot 6$ & $82 \cdot 5$ \\
\hline$" \quad$ (Deniker) & $\cdots$ & $\cdots$ & 1587 & - & - & - \\
\hline $\begin{array}{lll}\text { Javanese } & \ldots & \ldots\end{array}$ & $\cdots$ & $\ldots$ & $1570 \cdot 6$ & $177 \cdot 6$ & $150 \cdot 8$ & $85 \cdot 0$ \\
\hline$" \quad$ (Hagen $). .$. & $\cdots$ & $\cdots$ & $1606 \cdot 4$ & $177 \cdot 7$ & $151 \cdot 0$ & $84 \cdot 6$ \\
\hline$" \quad$ (Deniker) & $\cdots$ & $\ldots$ & 1616 & - & - & $84 \cdot 6$ \\
\hline Sundanese ... $\quad \ldots$ & $\cdots$ & $\cdots$ & $1591 \cdot 3$ & $176 \cdot 9$ & $151 \cdot 2$ & $85 \cdot 5$ \\
\hline$" \quad$ (Hagen) & $\cdots$ & $\cdots$ & $1588 \cdot 2$ & $174 \cdot 4$ & $152 \cdot 4$ & $86 \cdot 9$ \\
\hline$" \quad$ (Deniker) & $\ldots$ & $\ldots$ & 1591 & - & - & $86 \cdot 3$ \\
\hline
\end{tabular}

The greatest difference between the sets of measurements is in the stature of the Javanese.

\section{b. Standard deviation and Coefficient of Variability.}

The Egyptian series of Myers ${ }^{3}$ and those of Sardinians, Cretans, and Corsicans, quoted by Duckworth, ${ }^{4}$ are the only figures for the living subject that I have been able to employ in my comparisons.

1 "The Races of Man," by J. Deniker, Sc.ID.

2 "Anthropologische Studien aus Insulinde," von Dr. B. Hagen, Natuurk., Natuurk. Verh. der Koninkl. Akadamie, Deel xxviii, Amsterdam, 1890.

3 "Contributions to Egyptian Anthropometry," by Charles S. Myers, Journal of the Anthropological Institute, vol. xxxvi, 1906, pp. 237-271.

4 "A study of the Craniology of the Modern Inhabitants of Sardinia," by W.L. H. Duckworth, Zeitschrift fuir Morphologie und Anthropologie, Band xii, Heft 3, ss. 439-504. 
T. R. H. GarreTT.-The Natives of the Eastern Portion of Borneo and Java. 57

The remainder are taken from MacDonnell's ${ }^{1}$ paper on the Human Skull.

\begin{tabular}{|c|c|c|c|c|c|c|c|c|c|c|c|}
\hline & & \multicolumn{2}{|c|}{$\begin{array}{c}\text { Head } \\
\text { Length. }\end{array}$} & \multicolumn{2}{|c|}{$\begin{array}{c}\text { Head } \\
\text { Breadth. }\end{array}$} & \multicolumn{2}{|c|}{$\begin{array}{l}\text { Vertical } \\
\text { Radius. }\end{array}$} & \multicolumn{2}{|c|}{$\begin{array}{l}\text { Nasal } \\
\text { Height. }\end{array}$} & \multicolumn{2}{|c|}{$\begin{array}{c}\text { Nasal } \\
\text { Breadth. }\end{array}$} \\
\hline & & $\sigma$ & C. & $\sigma$ & C. & $\sigma$ & C. & $\sigma$ & C. & $\sigma$ & C. \\
\hline Banjerese & ... & $6 \cdot 22$ & $3 \cdot 44$ & $6 \cdot 77$ & $4 \cdot 59$ & $4 \cdot 76$ & $3 \cdot 59$ & $3 \cdot 19$ & $7 \cdot 18$ & $2 \cdot 68$ & $6 \cdot 89$ \\
\hline Sundanese & .. & $5 \cdot 28$ & 3.93 & $5 \cdot 24$ & $3 \cdot 47$ & $6 \cdot 62$ & $4: 97$ & $2 \cdot 39$ & $5 \cdot 30$ & $2 \cdot 45$ & $6 \cdot 27$ \\
\hline Javanese & ... & $4 \cdot 68$ & $2 \cdot 63$ & $4: 57$ & $3 \cdot 03$ & 3.90 & $4 \cdot 19$ & $4 \cdot 33$ & $9 \cdot 56$ & $1 \cdot 94$ & $5 \cdot 05$ \\
\hline Moslems (Egypt) & ... & $6 \cdot 09$ & $3 \cdot 13$ & $4 \cdot 34$ & $3 \cdot 01$ & $4 \cdot 65$ & $2 \cdot 83$ & - & - & - & - \\
\hline Copts (Egypt) ... & ... & $6 \cdot 13$ & $3 \cdot 17$ & $5 \cdot 09$ & $3: 56$ & $4 \cdot 15$ & $2 \cdot 83$ & $3 \cdot 41$ & $7 \cdot 14$ & $2 \cdot 72$ & $7 \cdot 57$ \\
\hline English (Skulls) & ... & $6 \cdot 27$ & $3 \cdot 31$ & $5 \cdot 28$ & $3 \cdot 75$ & $4 \cdot 28$ & $3 \cdot 73$ & $2 \cdot 60$ & $5 \cdot 08$ & $2 \cdot 16$ & $8 \cdot 89$ \\
\hline Sardinians (Skulls) & ... & $6 \cdot 43$ & $3 \cdot 48$ & $5 \cdot 32$ & $4 \cdot 03$ & $3 \cdot 99$ & 3.53 & $3 \cdot 75$ & $7 \cdot 50$ & $2 \cdot 12$ & $8 \cdot 89$ \\
\hline Ainu $^{2}$ (Skulls) ... & $\cdots$ & - & $3 \cdot 20$ & - & $2 \cdot 76$ & 一 & $3 \cdot 67$ & $2 \cdot 16$ & $8 \cdot 89$ & - & - \\
\hline
\end{tabular}

Taking the coefficient of variation, the Banjerese, as to the head length, resemble the Egyptian, English, Sardinian, and Ainu; whereas the Sundanese show slightly less, and the Javanese distinctly less, variability than these. But for the head breadth the variability of the Banjerese is markedly greater than that of any of the others, whilst that of the Sundanese is about the same as that of the English and Egyptians, distinctly less than that of the Sardinians and distinctly greater than that of the Ainu, and that of the Javanese is about the same as that of the Egyptians and Ainu, but very much less than that of the English and Sardinians. As regards the vertical radius, the variability of all three Malayan races is distinctly higher than that of the Egyptians, but the Banjerese resemble the English, Sardinians, and Ainu, whilst the Javanese are slightly more variable than these, and the Sundanese very much more so. The nose measurements of the English, Sardinian, and Ainu, having been made on the skull, are hardly comparable. In nasal height the Sundanese show distinctly less, the Banjerese about the same, and the Javanese distinctly more variability than the Copts, whilst in the breadth of the nose all three Malayan peoples show less variability than the Copts.

1 "Variation and Correlation of the Human Skull with Special Reference to English Crania," by W. R. MacDonnell, LL.D., Biometrika, vol. iii, pp. 191-244.

${ }^{2}$ Alice Lee, Phil. Trans., vol. clxxxxvi, A, p. 230. 
58 T. R. H. GarreTt.-The Natives of the Eastern Portion of Borneo and Java.

Turning now to the indices :-

\begin{tabular}{|c|c|c|c|c|c|c|c|c|c|c|}
\hline & & & \multicolumn{2}{|c|}{ Cephalic. } & \multicolumn{2}{|c|}{ Vertical. } & \multicolumn{2}{|c|}{ Upper Facial. } & \multicolumn{2}{|c|}{ Nasal. } \\
\hline & & & & C. & & C. & & C. & & C. \\
\hline Banjerese & $\ldots$ & $\ldots$ & $4 \cdot 46$ & $5 \cdot 47$ & $2 \cdot 81$ & $3 \cdot 84$ & $2 \cdot 92$ & $6 \cdot 26$ & $7 \cdot 81$ & $.8 \cdot 88$ \\
\hline Sundanese & ... & $\ldots$ & $3 \cdot 18$ & $3 \cdot 72$ & $3 \cdot 22$ & $4 \cdot 27$ & $2 \cdot 65$ & $5 \cdot 76$ & $7 \cdot 76$ & $8 \cdot 93$ \\
\hline Javanese... & $\ldots$ & $\ldots$ & $3 \cdot 45$ & $4 \cdot 06$ & $3 \cdot 46$ & $4 \cdot 59$ & $3 \cdot 70$ & $7 \cdot 98$ & $9 \cdot 18$ & $10 \cdot 72$ \\
\hline \multicolumn{2}{|c|}{ Moslems (Egypt) } & $\cdots$ & $2 \cdot 86$ & $3 \cdot 85$ & - & - & 3.53 & $7 \cdot 29$ & $7 \cdot 67$ & $10 \cdot 12$ \\
\hline \multicolumn{2}{|c|}{ Copts (Egypt) ... } & $\cdots$ & $3 \cdot 48$ & $4 \cdot 70$ & - & - & $3 \cdot 18$ & 6.55 & $8 \cdot 16$ & $10 \cdot 77$ \\
\hline \multicolumn{2}{|c|}{ English (skulls) } & $\ldots$ & $3 \cdot 26$ & $4 \cdot 38$ & $3 \cdot 22$ & $4 \cdot 61$ & - & - & $4 \cdot 58$ & $9 \cdot 64$ \\
\hline \multicolumn{2}{|c|}{ Sardinians (skulls) } & $\cdots$ & $3 \cdot 36$ & $4 \cdot 80$ & $3 \cdot 24$ & $4 \cdot 56$ & - & - & $5 \cdot 01$ & $10 \cdot 02$ \\
\hline \multicolumn{3}{|c|}{$\begin{array}{lll}\text { Ainu (skulls) } & \ldots & \ldots\end{array}$} & $2 \cdot 41$ & - & - & - & - & - & - & - \\
\hline \multicolumn{3}{|c|}{ Sardinians (living), Livi } & 3.98 & $5 \cdot 13$ & - & - & 一 & - & - & - \\
\hline \multicolumn{3}{|c|}{ Cretans (living), Hawes } & $4 \cdot 10$ & $5 \cdot 17$ & - & - & - & - & - & - \\
\hline \multicolumn{3}{|c|}{ Corsicans (living) } & $2 \cdot 90$ & $3 \cdot 82$ & - & - & 一 & - & - & - \\
\hline
\end{tabular}

The coefficient of variation for the breadth index of the Banjerese is very markedly higher than that of any of the others, except of the living Sardinians and Cretans, than whose it is only slightly higher; whilst that of the Sundanese is slightly lower than that of the others, except the living Sardinians and Cretans, than whose it is distinctly lower; whilst that of the Javanese is much about the same as that of the Egyptian Moslems, Corsicans, and English, but distinctly lower than that of the Sardinians and Cretans.

In the case of the vertical index I have only the English and Sardinian skulls with which to compare them, and here the Javanese show the same variability, the Sundanese slightly less, and the Banjerese distinctly less than these skulls.

As for the upper facial index the Javanese show more variability than the Egyptians, whilst the Banjerese and Sundanese show distinctly less. And in the nasal index the variability of the Javanese, whilst higher than that of the English and Sardinian skulls, is much about the same as that of the Egyptians, but that of Banjerese and Sundanese is distinctly less than that of the English, Sardinians, or Egyptians.

To sum up, with regard to their heads the Banjerese show distinctly less variability in the absolute measurements than do the Sardinian skulls, about the same as the Ainu skulls, slightly more than the Sundanese or the English skulls, and considerably more variability than the Egyptians and Javanese, whilst in the indices they show less variability than the Egyptians, Javanese, and the English skulls. 
The Sundanese show less variability in the measurements than do the Sardinian skulls, about the same as the Egyptians, but less than the English and Ainu skulls, and considerably less than the Javanese, whilst in the indices the variability is much less than in any of the others.

The Javanese in the measurements show rather less variability than the Egyptians or the English skulls, about the same as the Sardinian skulls, and distinctly more than the Ainu skulls, whilst in the indices the variability is about the same as in the English and Sardinian skulls, and rather greater than that of the Egyptians.

\section{Legenda to Table 1.}

The only items which call for explanation are the following :-

Age.-Very few of the subjects could give their age exactly unless they had happened to be born about the time of some striking event, such as the Krakatau explosion. Hence, if the third molars were fully erupted I put the age at about 25 , unless the appearance of the subject differed markedly from this age, or he himself was very certain that this was wrong.

Colour of Skin.-This is described according to Plate III in the British Association's Notes and Queries on Anthropology, 1899.

Colour of Eye.-This is described in accordance with the Augenfarben Tafel of Prof. Rud. Martin.

\section{Legenda to Table 2.}

In Table 2 the figures at the heads of the columns have the following significations :-

\section{Stature.}

2. Span of Arms.

3. " " Ratio of, to Stature 1,000.

4. Height sitting.

5. " " Stature 1,000.

6. Chest, Circumference, Deep Inspiration.

7. " ",$\quad$ N $\quad$ Stature 1,000 .

8. " $" \quad$ Complete Expiration.

9. " " " " $"$ Stature 1,000.

10. „ Lateral Diameter, Deep Inspiration.

11. " " " " " $"$ Stature 1,000.

12. " " $\quad$ " Complete Expiration.

13. " " " " " $"$ Stature 1,000 .

14. " Antero-Posterior Diameter, Deep Inspiration.

15. . " " " " ",$\quad$ Stature 1,000 .

16. " " " $\quad$ Complete Expiration.

17. " " $" \quad$ ",$\quad$ Stature 1,000 . 


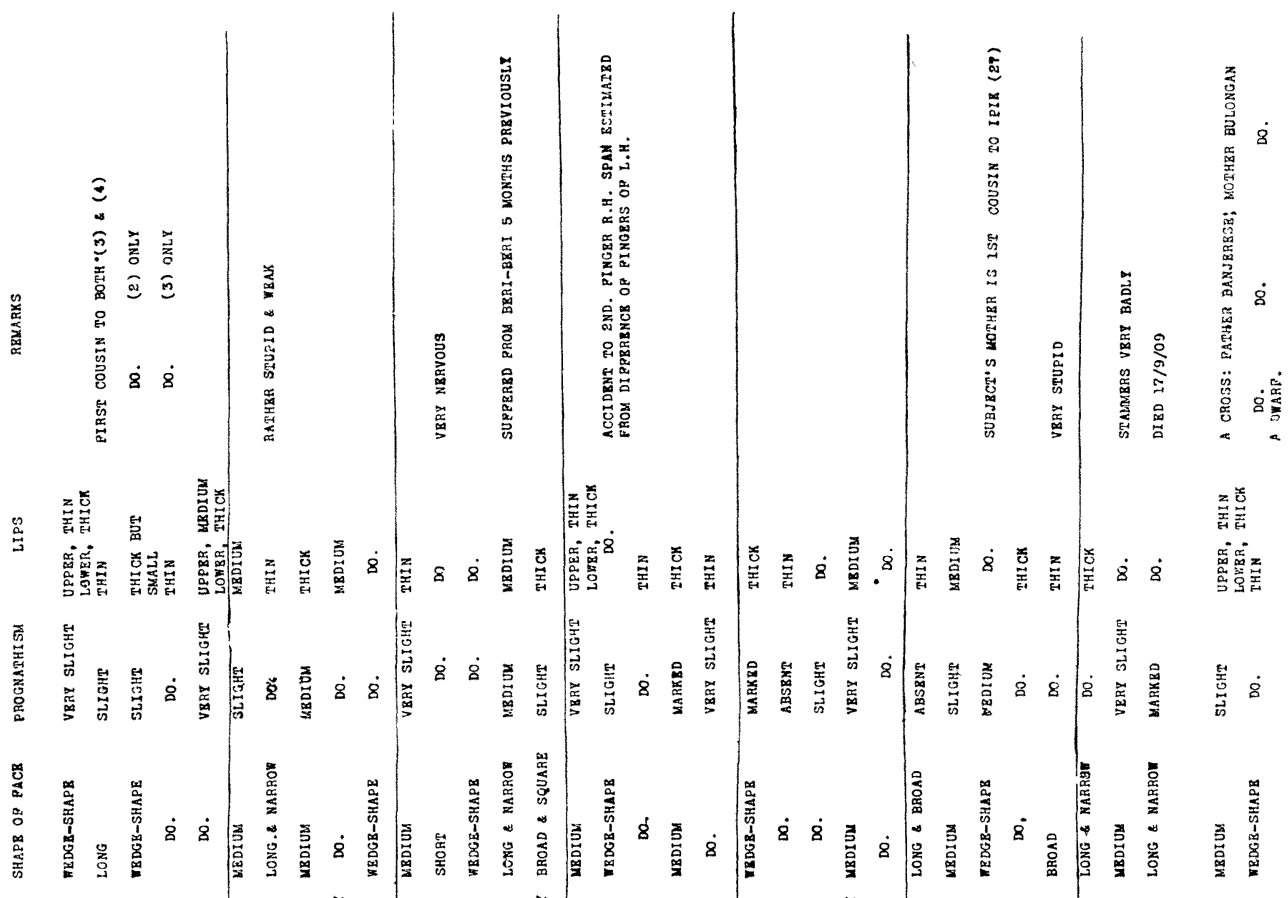

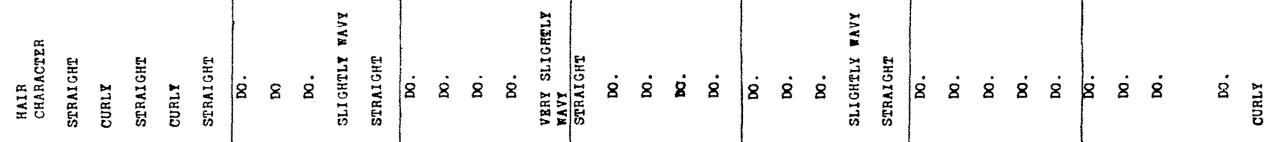

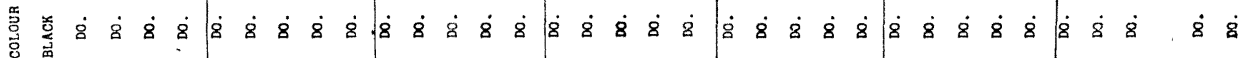

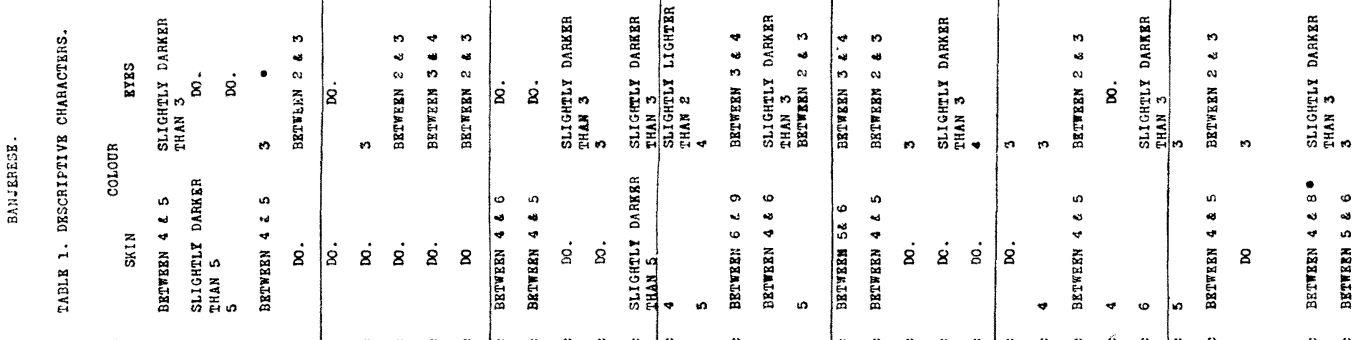

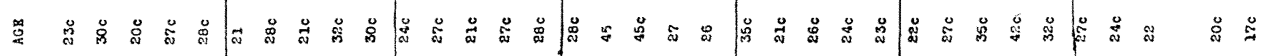
MIn

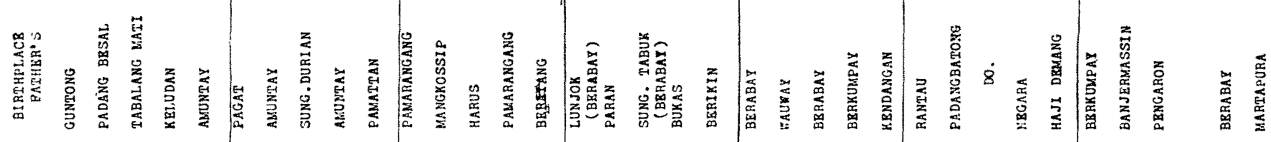

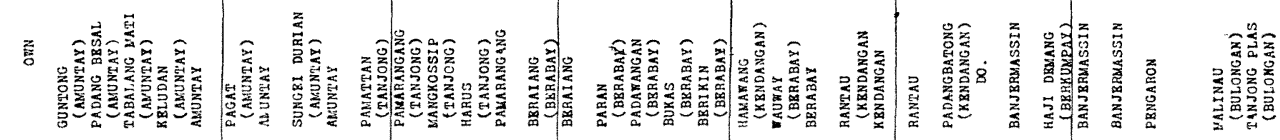

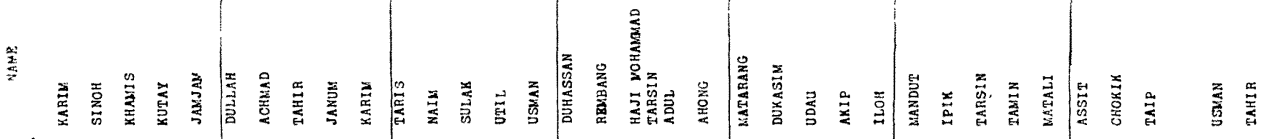

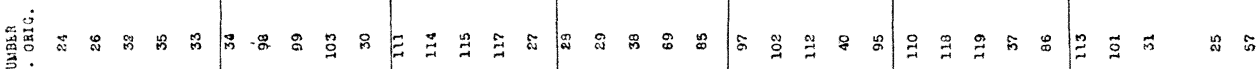

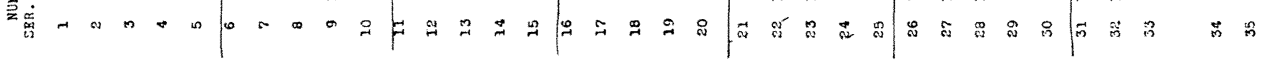


م

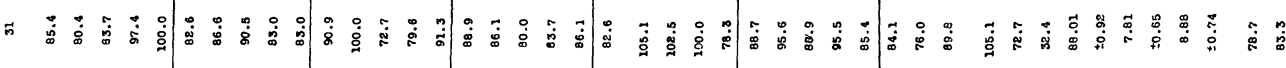
ฉ \& की

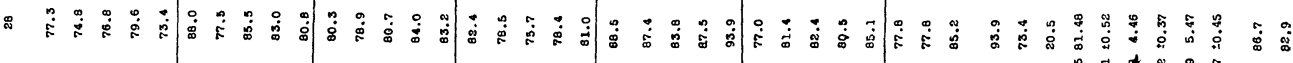
¿

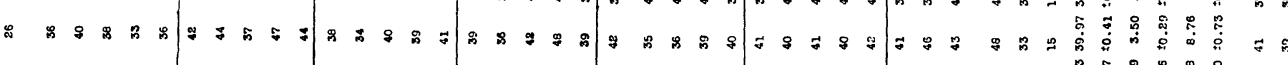
足

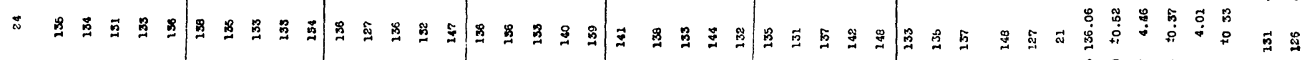

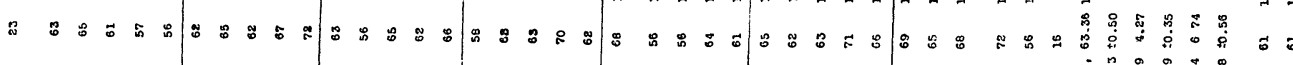
๙ ๘ 员

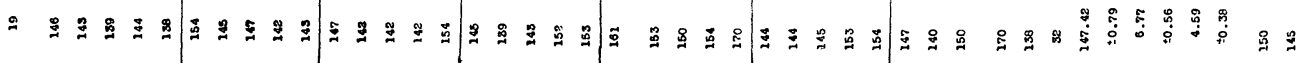

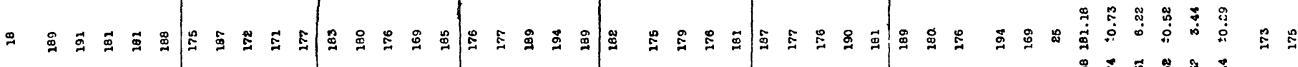

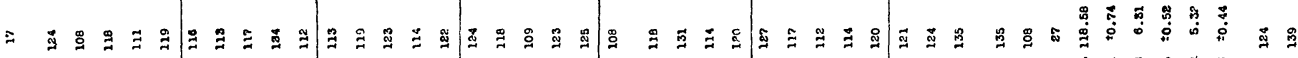

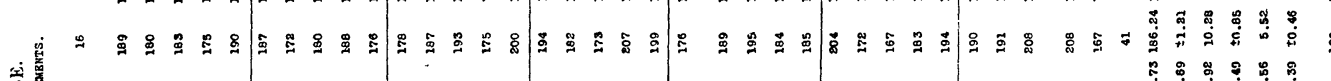
$\stackrel{8}{8}$ 口

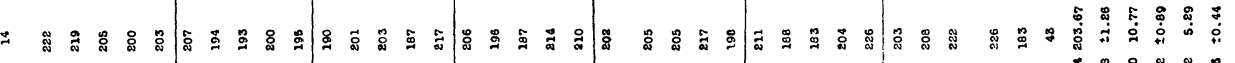

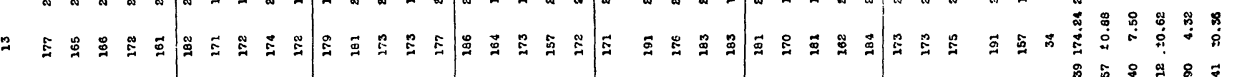

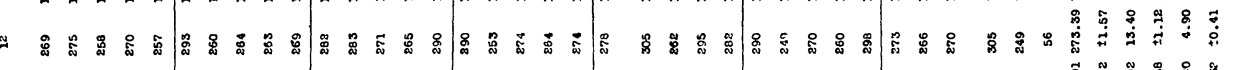

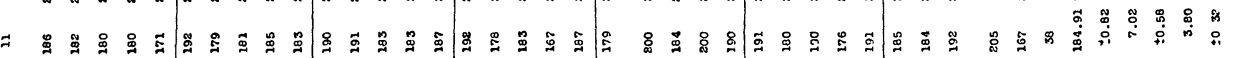

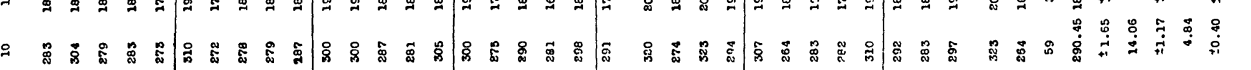

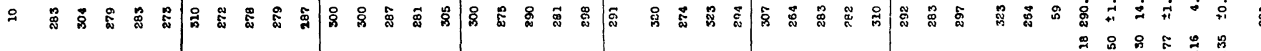

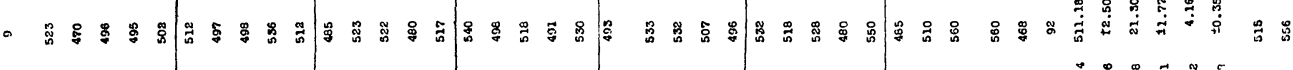

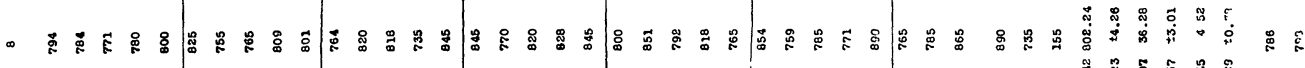

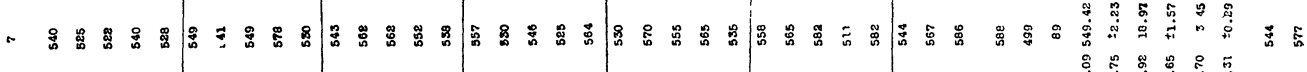

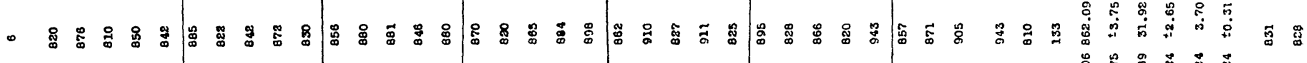

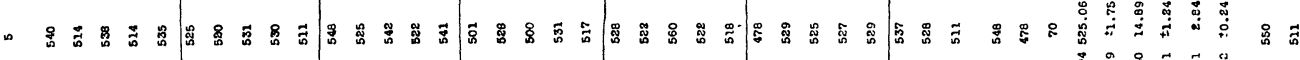

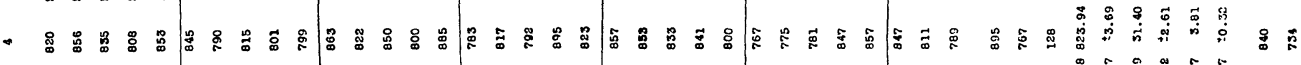

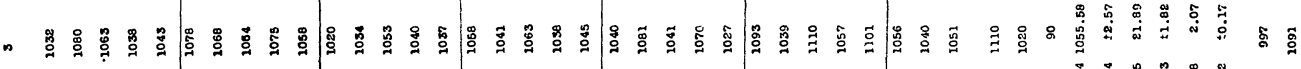

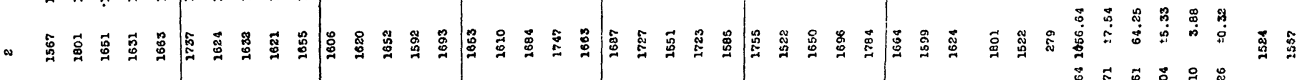

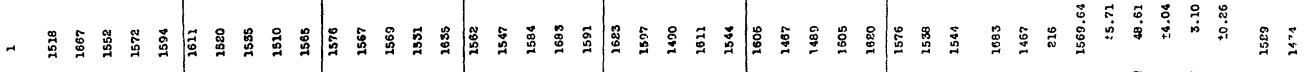

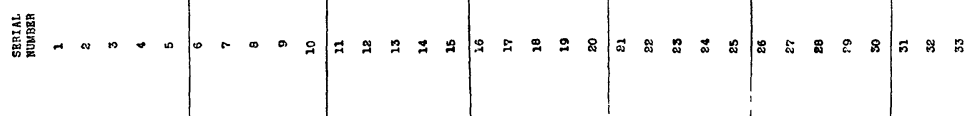




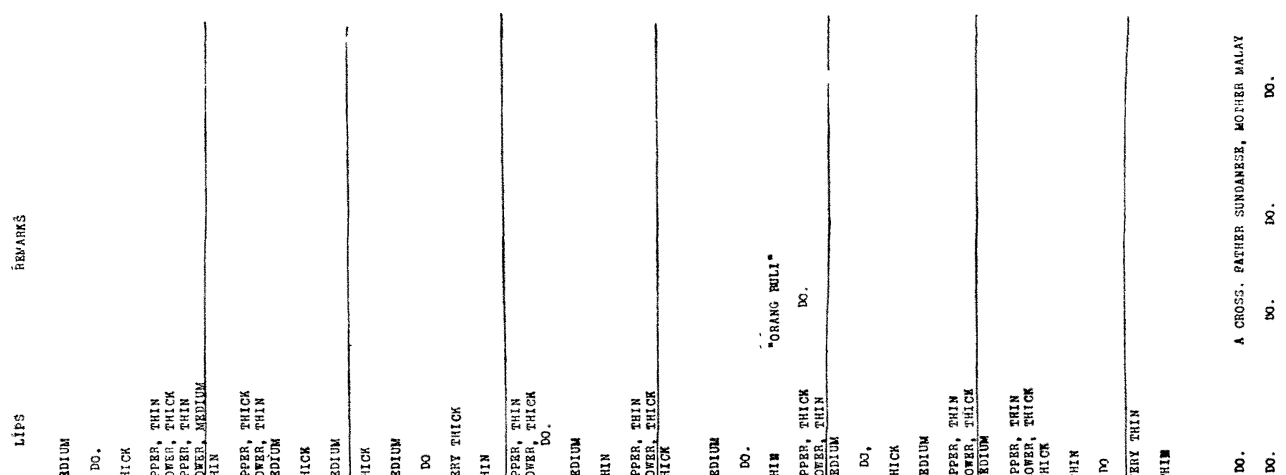

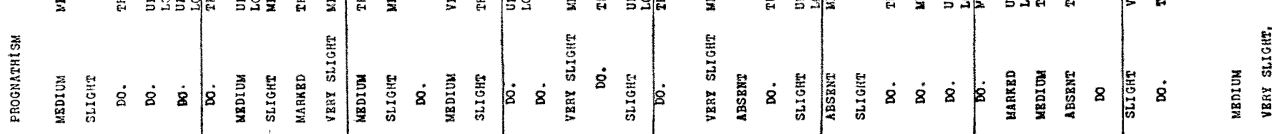

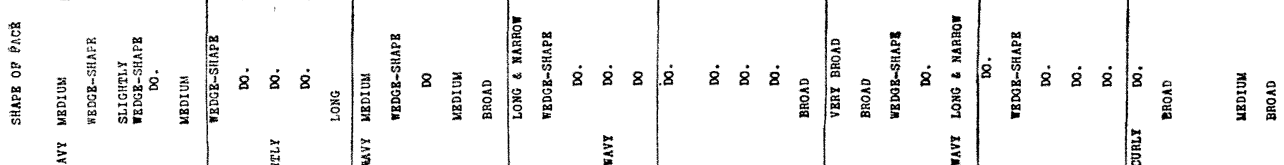

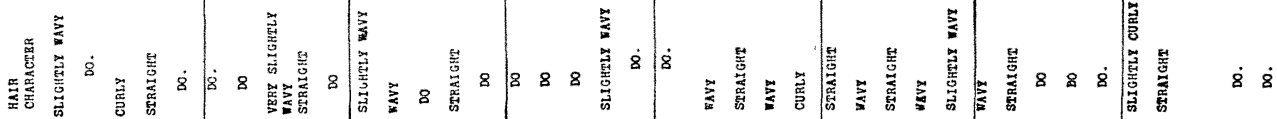

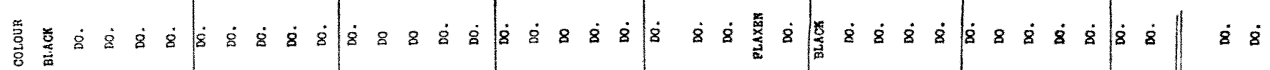

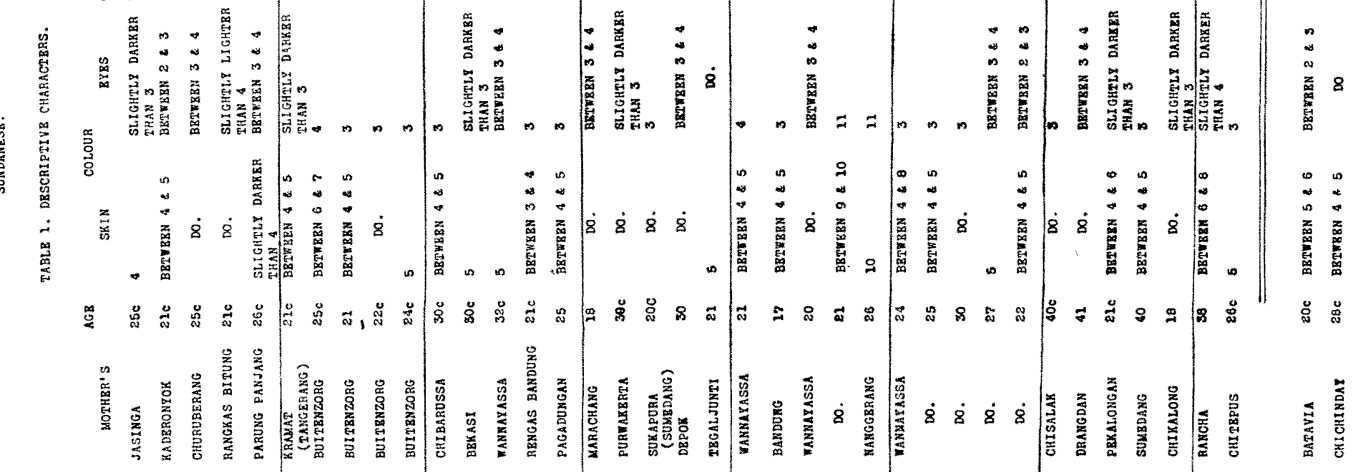

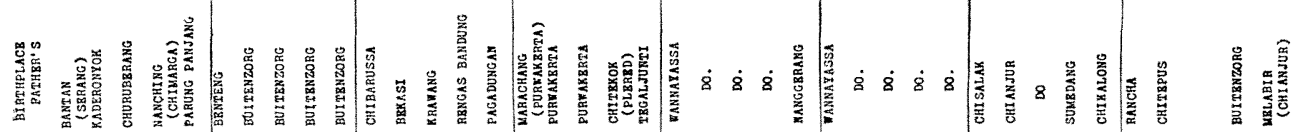

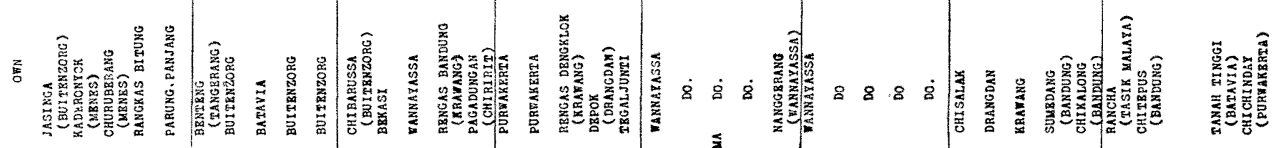

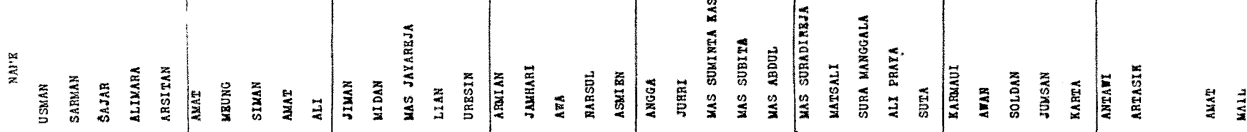

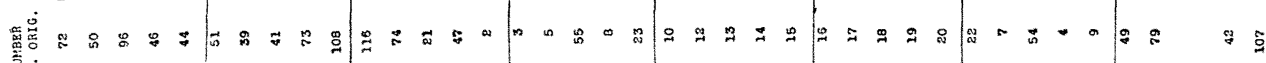

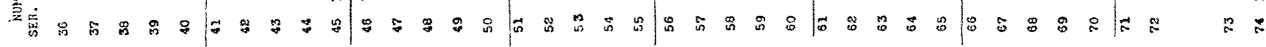




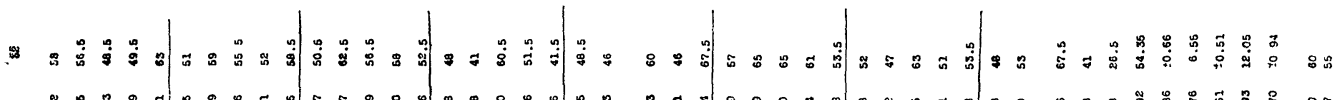

क

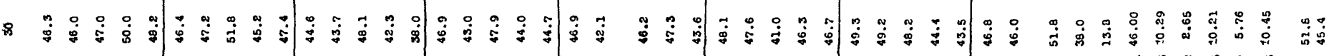

\&

ஐ

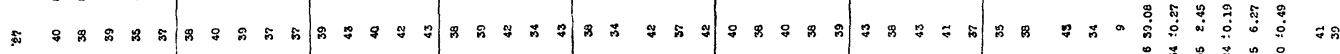

正

พั7

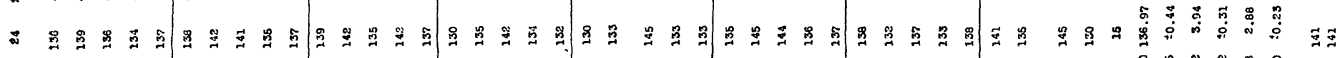

ะ

ฐ

๘.

๙

- 虽

马

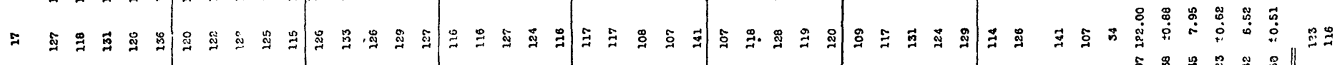

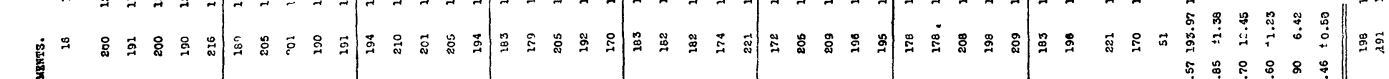

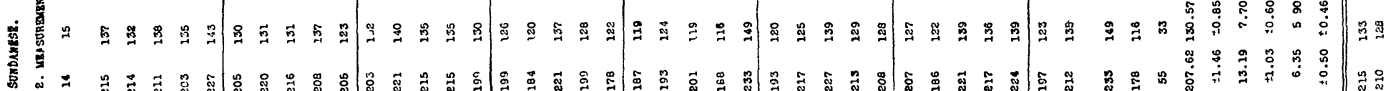

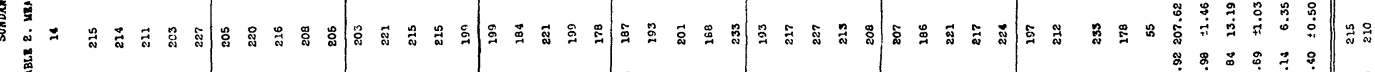

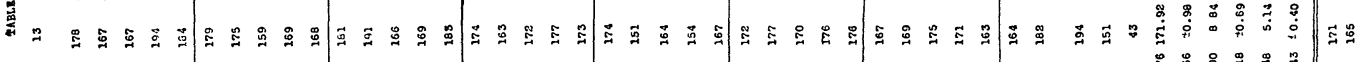

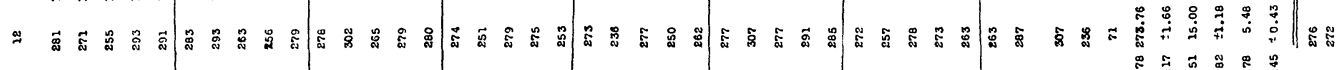

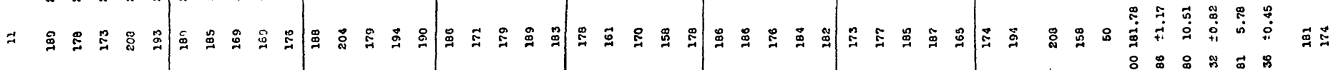
-

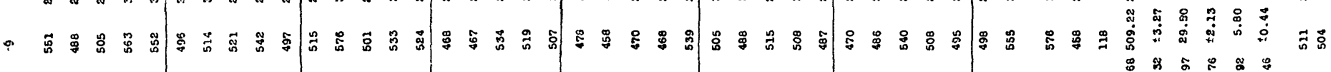

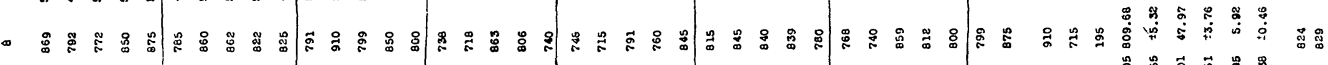

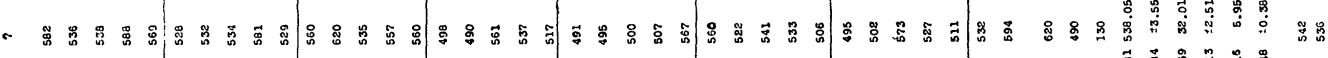

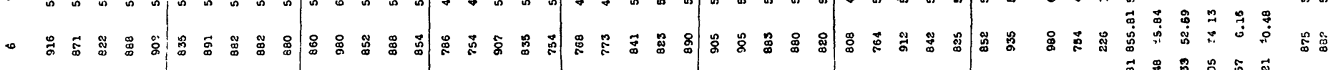

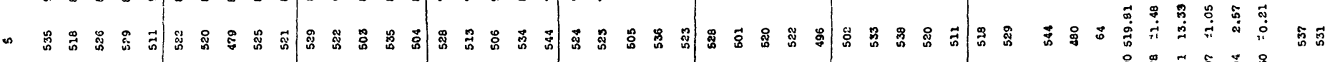

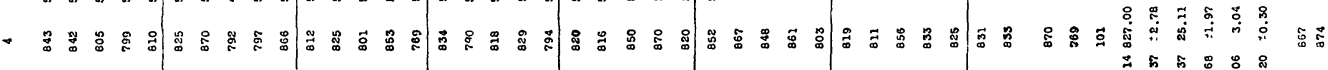

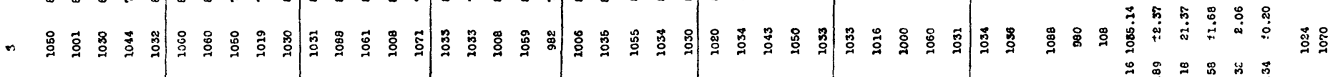

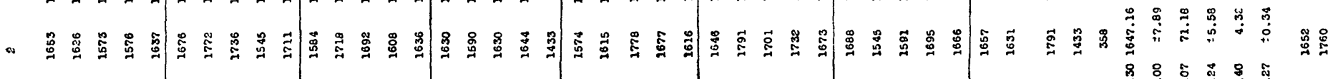

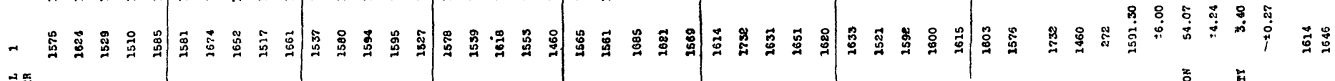

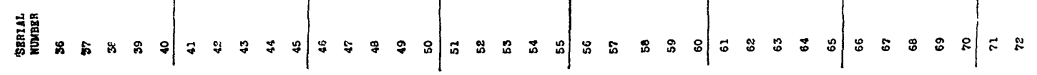


jAVẠESE.

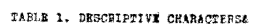

\begin{tabular}{|c|c|c|c|}
\hline \multicolumn{2}{|c|}{$\begin{array}{l}\text { RUMBEA } \\
\text { Szi. OFis. }\end{array}$} & 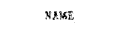 & \multirow{2}{*}{ 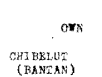 } \\
\hline 75 & $n$ & NUSAB & \\
\hline 76 & 6 & RATSB SOSA WIAA"A & PURVAKRPEA \\
\hline $7 ?$ & 49 & DARGAD & $\begin{array}{l}\text { losAn: } \\
\text { (CABRION) }\end{array}$ \\
\hline 28 & 109 & SAJAT & $\begin{array}{l}\text { PTAKAR } \\
\text { PERA1ECN) }\end{array}$ \\
\hline 79 & 1 & WAUNA & $\begin{array}{l}\text { CHIPAS } \\
\text { (PUBRA }\end{array}$ \\
\hline 80 & 84 & SINGOYOSO & 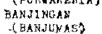 \\
\hline$\forall 1$ & 89 & HAS SONWEMADAKO & 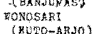 \\
\hline$\theta 2$ & 53 & SLAMZT & BONGAS \\
\hline 83 & 70 & MBRTODTKORO & SLAYMA \\
\hline 84 & 60 & SAI.BB & $\begin{array}{l}\text { (JOJA) } \\
\text { NABUMYN }\end{array}$ \\
\hline 85 & 61 & SURODIKF̆ROLO & $\begin{array}{l}\text { KNLY ORSO } \\
\text { KKLY }\end{array}$ \\
\hline 86 & .59 & SARIP & $\begin{array}{l}\text { GOAlO } \\
\text { GBTAS }\end{array}$ \\
\hline 87 & 64 & SARPAN & $\begin{array}{l}\text { (SARARANG) } \\
\text { SAMARANG }\end{array}$ \\
\hline 80 & 43 & XANDR1 & SURABAYA \\
\hline 89 & $\$ 2$ & NATOTO & $\begin{array}{l}\text { Ra: } \\
\text { (LAMTINOAN) }\end{array}$ \\
\hline & 60 & SARYDSN & SUTFALAN \\
\hline 91 & 22 & LAUT & $A T S B A$ \\
\hline
\end{tabular}

\begin{tabular}{|c|c|c|c|c|}
\hline $\begin{array}{l}\text { 日I RPHFI.ACB } \\
\text { PATRRH'S }\end{array}$ & MOTHBR'S & $\operatorname{sog}$ & SKIN & $\operatorname{2xg}$ \\
\hline CHI BZLUT & BANEAN & $20 \mathrm{c}$ & SETVERM 4 \& 5 & 2 \\
\hline PUEW GKERTA & PUREAKRETA & 55 & Do. & 3 \\
\hline LOSARI & LOSARI & $3 \pm 0$ & FRP & 3 \\
\hline PALMKAN & PATEKAN & $26 \mathrm{c}$ & $8 B 2 \pi R E N 4$ \& 5 & RETERE $2 \approx 3$ \\
\hline TEGAL & TRGAL & $46 \mathrm{c}$ & Do. & Do. \\
\hline BANUINGAN & BANJINGAN & 31 & Do. & 3 \\
\hline $\begin{array}{l}\text { PAGRBANGAN } \\
\text { (XAPANG ANYZR) }\end{array}$ & monosagr & 24 & BEIUREN 647 & BET $38 R 283$ \\
\hline BONGAS & BOHGAS & $29 \mathrm{c}$ & 4 & 3 \\
\hline SLAYMAN & SLAYMAN & $25 \mathrm{c}$ & 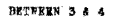 & BRTFERN 283 \\
\hline MABUMIEM & MABUMEN & $40 c$ & BETFBEM $4 \& 5$ & 4 \\
\hline KAL 1 ORSO & BATAVIA & $33 \mathrm{e}$ & DO. & 3 \\
\hline GETAS & GETAS & $23_{c}$ & ARTEREN 406 & 4 \\
\hline SAMARANG & SAMARANG & $25 \mathrm{c}$ & BXIFERE 4 \& & 2 \\
\hline SURABAYA & SURABRYA & 26 & $\infty$. & 3 \\
\hline BUMP1 & RUMPS & $19 s$ & 5 & 2 \\
\hline SOrALAM & SUWALAN & 250 & BETREBN $4 \& 6$ & BETFERN 288 \\
\hline XAPUIFAN & KAPUTARN & $25 \mathrm{e}$ & Do. & Do. \\
\hline
\end{tabular}

\begin{tabular}{|c|c|c|c|c|}
\hline Colour & $\begin{array}{l}\text { FAIR } \\
\text { rHABACTER }\end{array}$ & 5HAPB OP PACB & PRDGNAEHISM & tips \\
\hline BLACK & SรÄhIGHT & MEDI & Mototiom & THIN \\
\hline GRBR & to. & TEDOR-SHAPB & ABGENI & $\infty$. \\
\hline BLACK & DO. & Do. & YRAQ SLIOHZ & VRRE THIS \\
\hline no. & Do. & BROAD & MEDTUR & raICK \\
\hline no. & Do. & Mrorey & ABSEN? & IHIN \\
\hline Do. & Do. & BROAD & ERDiUM & MEDICW \\
\hline Do. & Do. & MBtTEN & $\infty$. & THIS \\
\hline Do: & EAYY & VEDGB-SHAPB & $\infty$. & no. \\
\hline Do. & SERAIGHT & Do. & YERY SLIGIT & DC. \\
\hline Do. & Do. & Do. & SLIGHT & THICX \\
\hline Do. & Do. & no. & $\infty$ & Madrun \\
\hline no. & Do, & Do. & MEDYon & Do. \\
\hline bo. & SLIGHTLY wAYY & Do. & Do. & $\begin{array}{l}\text { UPPEA, MBDITN } \\
\text { LORER, }\end{array}$ \\
\hline Do. & STAAIGHT & Do. & SLIGHI & MED10M \\
\hline Do. & SHIGHRLY CURLT & QROAD & VERY SL, $1 \mathrm{G} X \mathrm{Y}$ & mHS \\
\hline Do. & STRATGEY & HEDGB-5HAPE & SLYGH? & THICK \\
\hline Do. & no. & MBEIUM & Mrosum & MFDIUU \\
\hline
\end{tabular}

saraxkan.

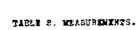

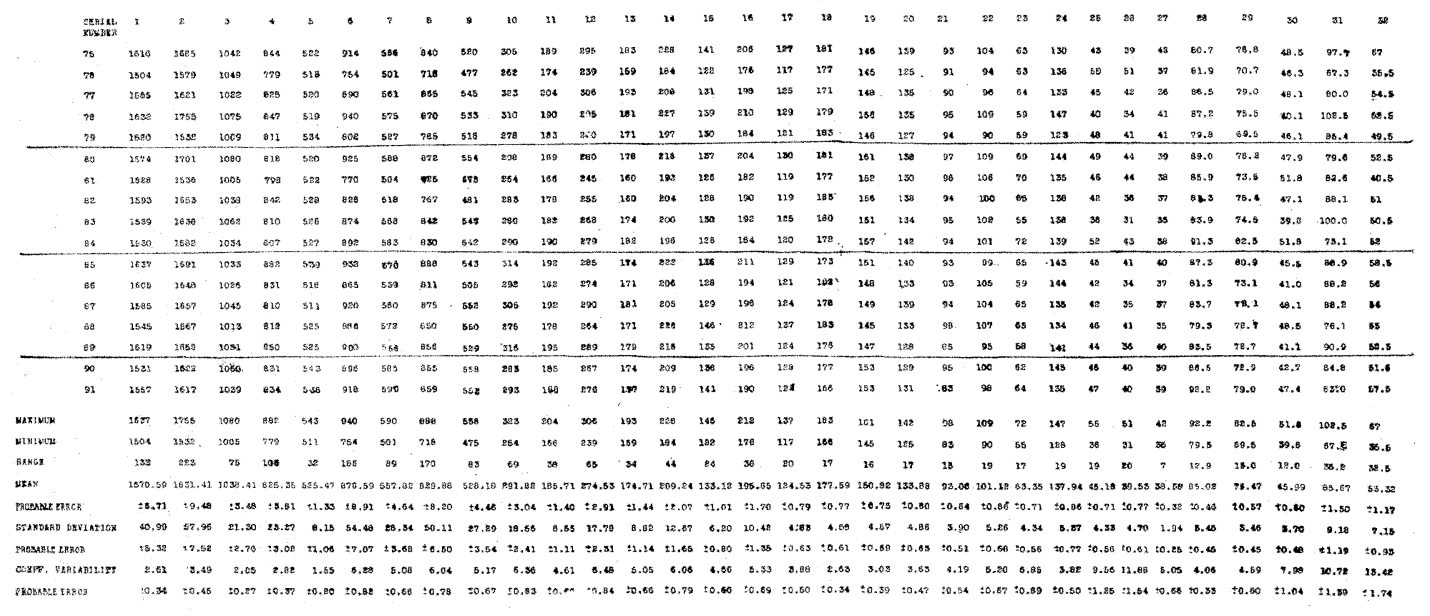


T. R. H. GaRReTt.-The Natives of the Eastern Portion of Borneo and Java.

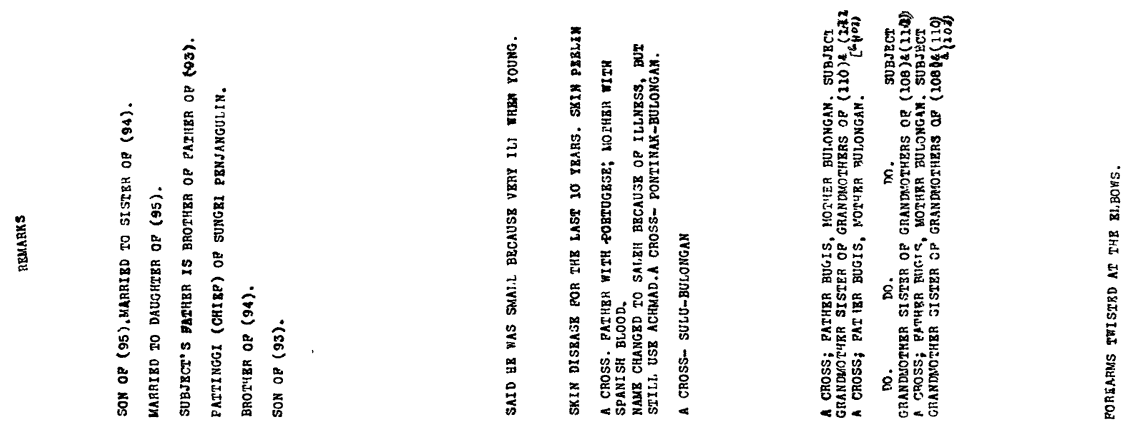

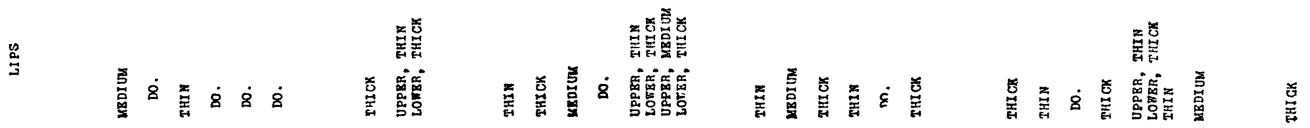

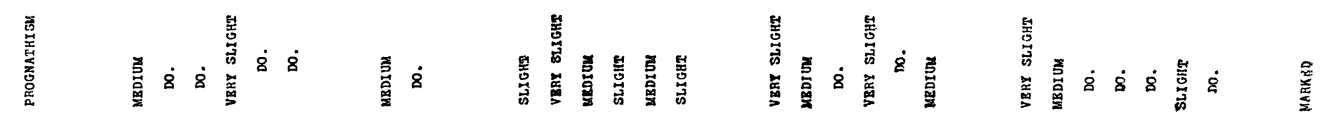

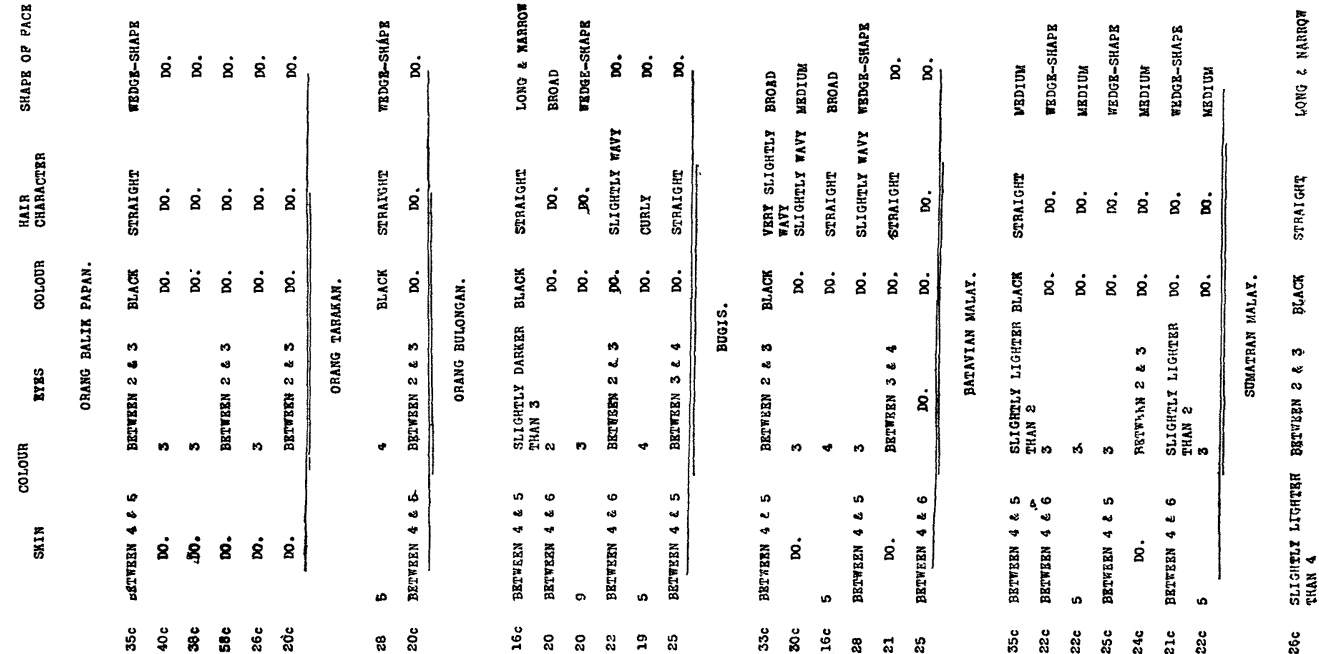

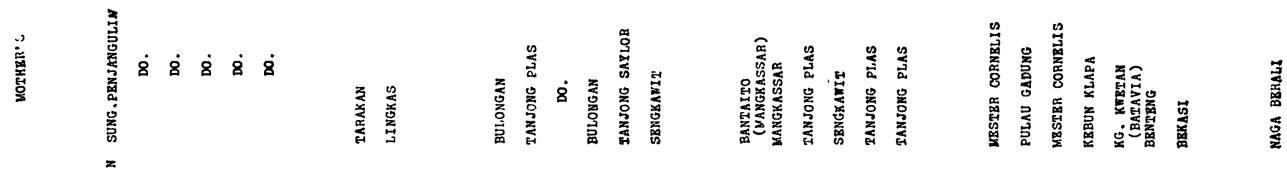
䕶 5

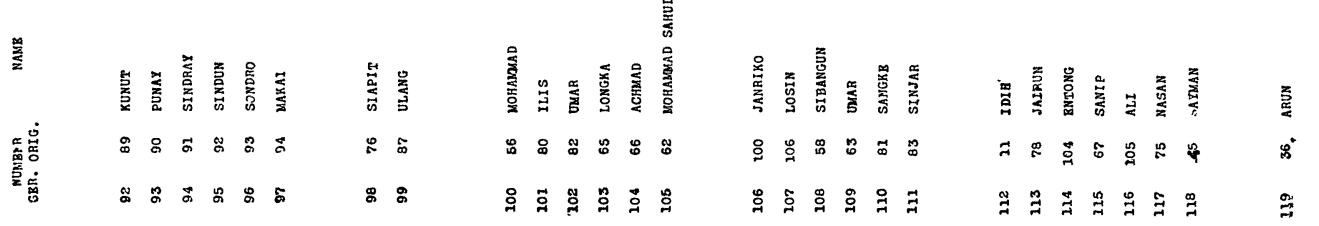
VOL. XLII. 


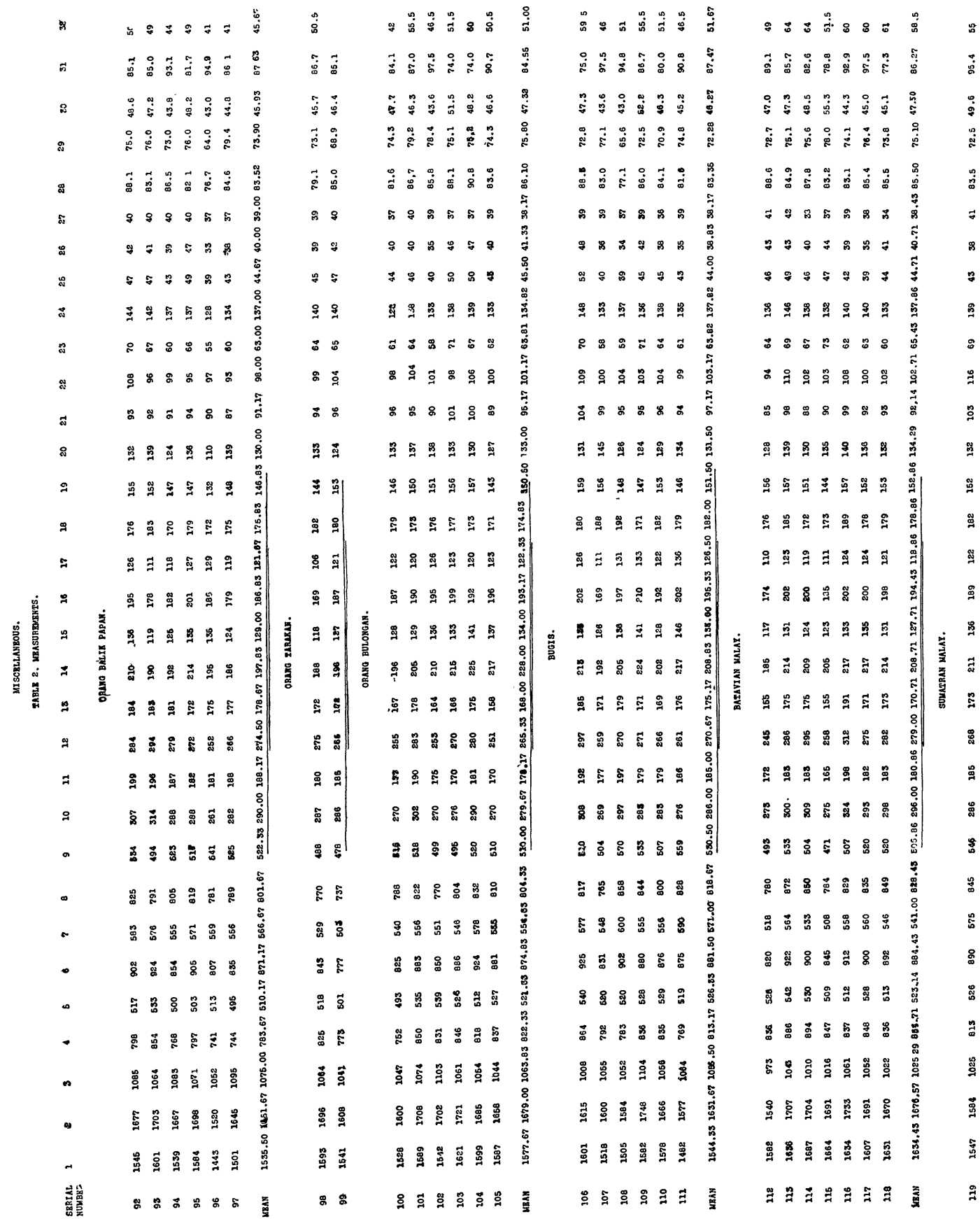


T. R. H. GarretT.-The Natives of the Eastern Portion of Borneo and Java. 67

18. Head, Length.

19. „ Breadth.

20. „ Radii, Vertical.

21. , ” Upper Nasal.

22. " ” Alveolar.

23. Face, Upper Length.

24. „ Maximum Inter-Zygomatic Breadth.

25. Nose, Height.

26. „ Length.

27. „ Breadth.

28. Indices, Cephalic.

29. „ Vertical.

30. ” Facial.

31. „ Nasal.

32. Weight in kilogrammes.

All of these measurements were made in accordance with the Report of the nthropometric Committee of the British Association, published by the Royal ..nthropological Institute. 